\title{
The dragonet Callionymus lyra, a target species used for evaluation of biological effects of chemical contaminants on French coasts
}

\author{
T. Burgeot ${ }^{1}$, G. Bocquené ${ }^{1}$, P. Truquet ${ }^{1}$, L. Le Déan ${ }^{1}$, J. C. Poulard ${ }^{1}$, D. Dorel ${ }^{1}$, \\ A. Souplet ${ }^{2}$, F. Galgani ${ }^{1}$ \\ ${ }^{1}$ IFREMER, rue de l'Ile d'Yeu, F-44037 Nantes Cedex, France \\ ${ }^{2}$ IFREMER, BP 699, F-62321 Boulogne sur Mer, France
}

\begin{abstract}
An oceanographic cruise in 1991 along the English Channel and Atlantic coasts of France indicated the value of dragonet Callionymus lyra Linnaeus, 1758 as a target species for monitoring biological effects. Ethoxyresorufin-O-deethylase measurements in this species provided a first assessment of the effects of hydrocarbons (PCB, PAH, dioxins) on the marine environment. The specific behavior of dragonet was defined by biochemical characterization. Biological data were obtained during 3 additional oceanographic cruises to study changes in the abundance and distribution of the species in the English Channel and the Bay of Biscay. This first assessment, carried out in the context of the National Observation Network, indicated that pollutants do not have important chronic effects on marine organisms collected along the Atlantic coasts except at a few heavily contaminated sites.
\end{abstract}

\section{INTRODUCTION}

The use of the ethoxyresorufin-O-deethylase (EROD) parameter to monitor biological effects constitutes a new approach in assessing pollution in marine ecosystems. The utility of measuring hydrocarbon induction of mixed function oxygenase (MFO) enzymes as a monitoring index has been widely demonstrated (Goksøyr et al. 1986, Goksøyr 1987, Stegeman et al. 1987, Payne et al. 1988, Spies et al. 1989). Cytochrome P-450-IA1 is induced in fish by a variety of aquatic pollutants including dioxins (Vodicnick et al. 1981), PAH (Addison \& Payne 1986, Van Veld et al. 1990) and some congeners of plane PCB (Gooch et al. 1989). EROD combined with cytochrome P-450-1A1 (Nebert et al. 1989) is an efficient tool for detecting pollutants (Suteau 1987, Stegeman \& Lech 1991). The fact that it can be analyzed directly on board oceanographic vessels (Galgani \& Bocquené 1991, Eggens et al. 1992) makes this parameter particularly suitable for monitoring purposes. A first oceanographic cruise in August-September 1991 along the English Channel and Atlantic coasts of
France validated EROD as a specific biomarker for routine monitoring. We demonstrated that dragonet Callionymus lyra Linneaus, 1758, a species of fish uniformly distributed along these coasts, was the most appropriate target species of fish for a monitoring network.

This species is quite familiar to taxonomists, but we found that relatively little was known about its biology along the French coast. Accordingly, we undertook a biochemical characterization of dragonet to understand its specific biochemical behavior better and to determine the optimal conditions for analysis of its enzymatic (EROD) activity. Data collected during 3 other surveys along the English Channel and Atlantic coasts of France from 1987 to 1991 provided information about its seasonal distribution

This first assessment of EROD activity in dragonet provided an estimate of the chronic toxicity of micropollutants of urban or industrial origin discharged along these coasts. The study constitutes a reference point for the 1992 start-up of a network capable of detecting sublethal effects within the relatively near future. 


\section{MATERIALS AND METHODS}

Sampling strategy and fish collection. Three surveys along the English Channel and Atlantic coasts of France provided previously unavailable data on changes in the abundance and distribution of Callionymus lyra (Figs. 1 to 3). The Channel Ground Fish Survey (CGFS) covered the North English Channel area from the Belgian frontier to Cherbourg from 1988 to 1991. The 'Pêche Cotière' (PECOS) survey covered the area from Cherbourg to the Gironde estuary during April, May and October from 1977 to 1982. Finally, the 'Evaluation des Ressources Halieutiques de l'Ouest de l'Europe' (EVHOE) cruises were carried out in the Bay of Biscay in autumn and spring from 1987 to 1991 . Taken together, these 3 series of cruises covered the entire western coast of France.

The sampling strategy used during EVHOE cruises was based on a stratification of the survey area according to latitude and depth. In the English Channel (CGFS survey), each ICES statistical rectangle $\left(30^{\prime}\right.$ in latitude by $1^{\circ}$ in longitude) was divided into 8 subrectangles, and a haul was done in each subrectangle. Large vertical opening bottom trawl fishing for a standard period of 30 min was performed during the day at each station. The EVHOE survey was carried out from $15 \mathrm{~m}$ to $600 \mathrm{~m}$ depth, and CGFS from 20 to $50 \mathrm{~m}$, whereas the PECOS cruise was more coastal within the 12 mile limit.

Another oceanographic cruise to determine the biological effects of contaminants by assaying EROD activity in dragonet was conducted along the English Channel and Atlantic coasts from 17 August to

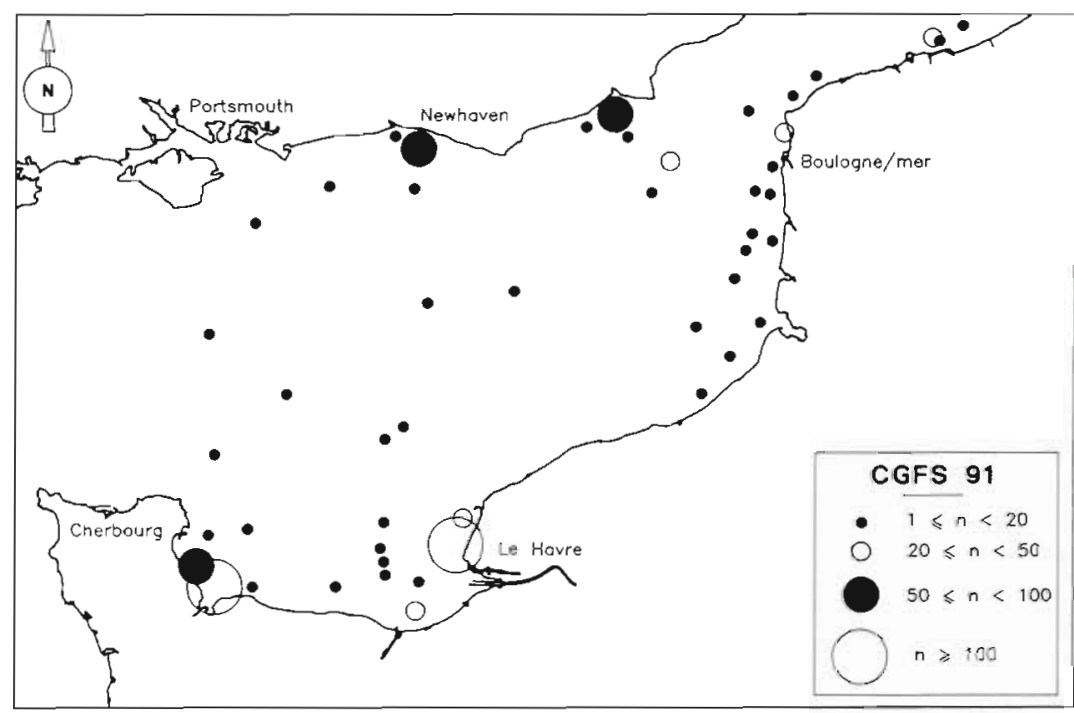

Fig. 1. Callionymus Iyra. Distribution along the English Channel coast observed during the CGFS cruise, 1991. ( $\mathrm{n}=$ no. of ind. per $30 \mathrm{~min}$ )

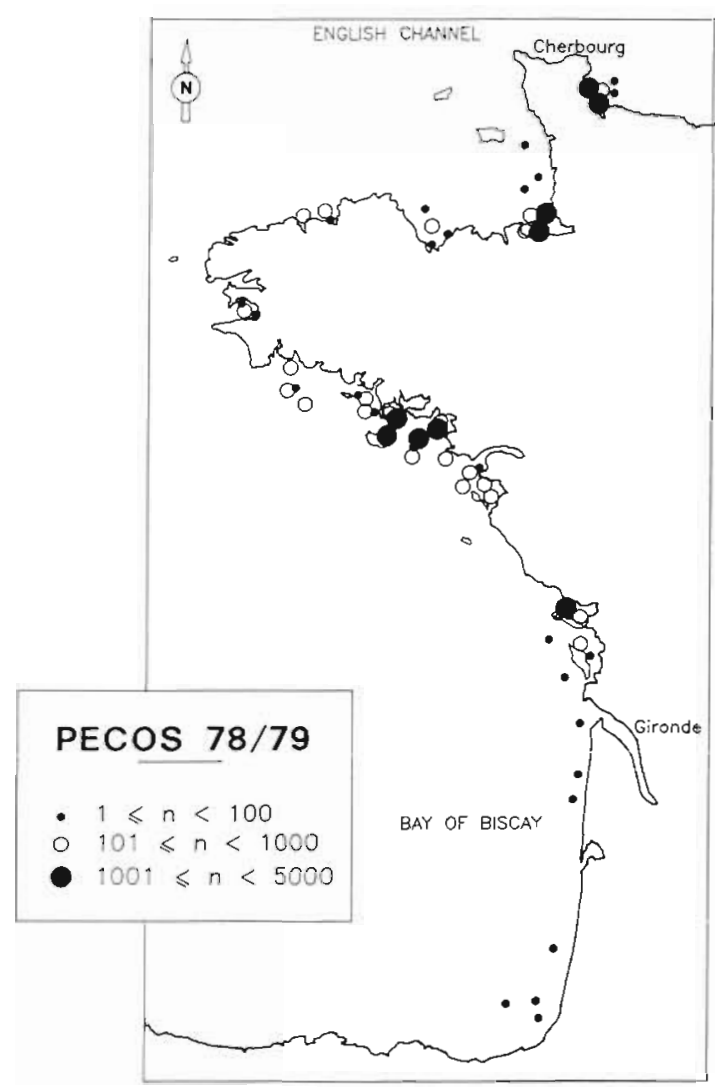

Fig. 2. Callionymus lyra. Distribution along the Atlantic coast of France observed during the PECOS cruise, 1978-1979. (n as in Fig. 1)

6 September 1991 (Fig. 4). Ten specimens trawl-fished at each station were measured and identified as to sex. From Stns 1 to 24, extractions and analyses were performed on board ship without sex differentiation. Samples from Stns 25 to 34 were frozen in liquid nitrogen and analyzed in the laboratory.

Chemical products. Resorufin, 7ethoxyresorufin, NADPH and metyrapone, a known inhibitor of $\mathrm{MFO}$ activities, were purchased from the Sigma Chemical Co

Preparation of extracts. Livers were washed in buffer (TRIS $50 \mathrm{mM}$, pH $7.4 ; \mathrm{KCl} 150 \mathrm{mM}$; EDTA $1 \mathrm{mM}$; and glycerol $20 \%$ vol) at $4{ }^{\circ} \mathrm{C}$ and then minced ( $5 \mathrm{ml} \mathrm{g}^{-\mathrm{t}}$ tissue) for 5 to $10 \mathrm{~s}$ in a Potter-Elvehjem tube before being centrifuged at $9000 \times g$ for $15 \mathrm{~min}$ at $4^{\circ} \mathrm{C}$. The supernatant was used as enzymatic solution.

Protein analysis. Proteins were measured in the supernatant according to the method of Bradford (1976) 

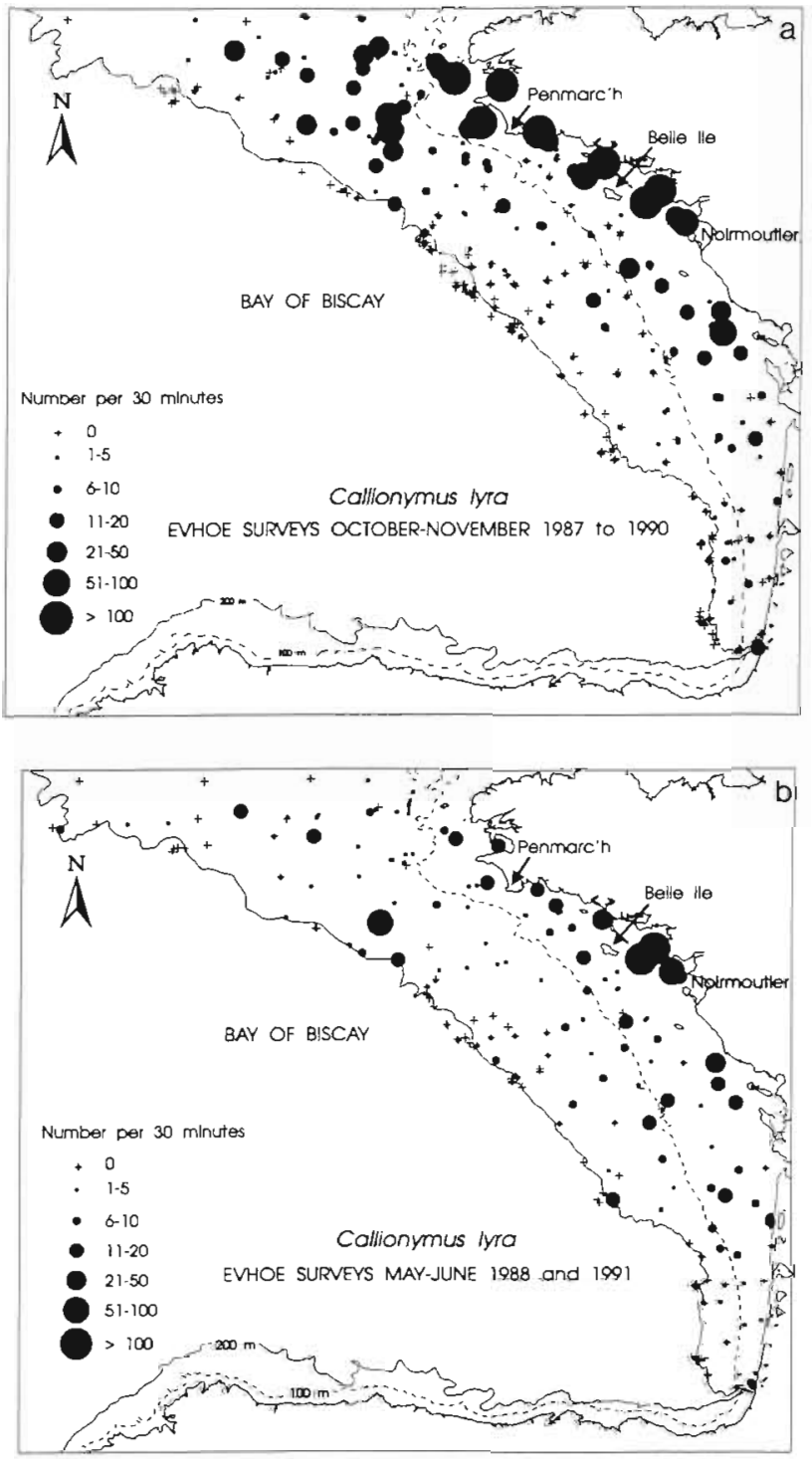

Fig. 3. Callionymus lyra. Distribution in the Bay of Biscay observed during the EVHOE surveys in (a) autumn 1987 to 1990 and (b) spring 1988 and 1991

using bovine serum albumin as protein standard Measurements were done with a platereading spectrophotometer at $595 \mathrm{~nm}$ and expressed as $\mathrm{mg} \mathrm{ml}^{-1}$.

Analysis of EROD activity. Analyses were performed at $4{ }^{\circ} \mathrm{C}$ in a buffer (TRIS $0.1 \mathrm{M}, \mathrm{pH} 8$; NaCl $0.1 \mathrm{M}$ ) containing $2 \mu \mathrm{M}$ of 7 -ethoxyresorufin and $0.25 \mathrm{mM}$ of NADPH. Activity was determined by kinetic measurement at room temperature $\left(22^{\circ} \mathrm{C}\right)$ in supernatant according to Addison \& Payne (1986), and the quantity of resorufin (the specific product of EROD activity) was determined. Fluorometric measurement (Galgani \& Bocquené 1989) was performed according to a modified method of Burke \& Mayer (1974), with excitation at $544 \mathrm{~nm}$ and emission at $584 \mathrm{~nm}$. Kinetics were deter-

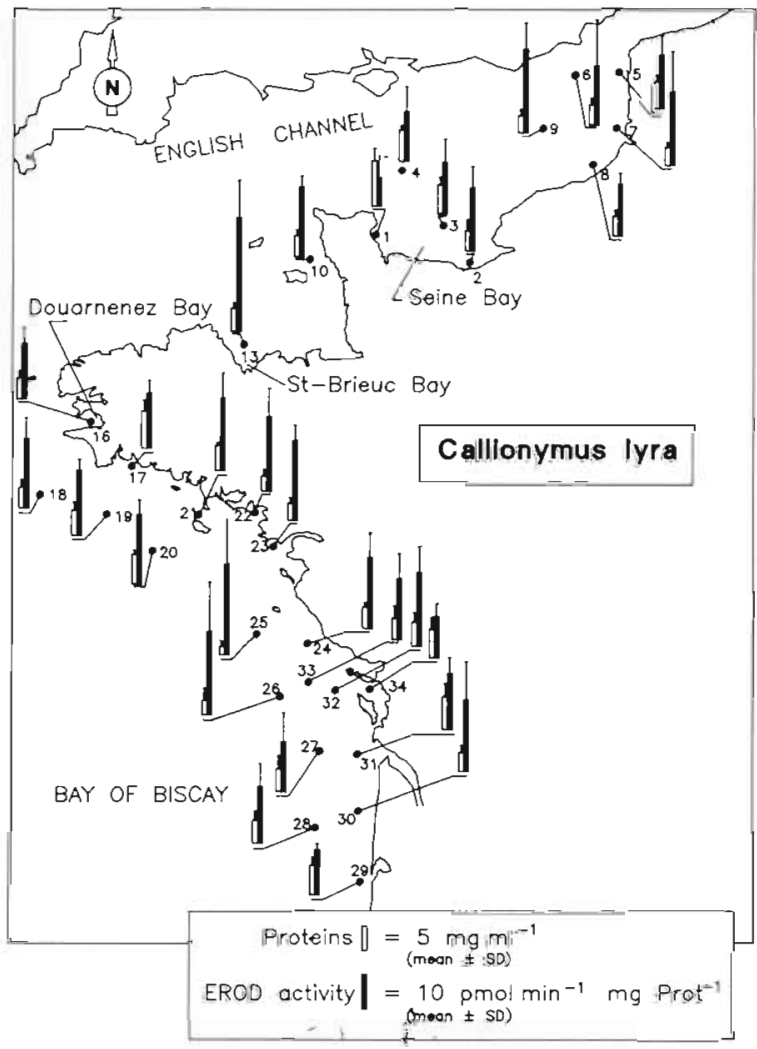

Fig. 4. Callionymus lyra. Measurements of EROD activity associated with a protein assay along the English Channel and Atlantic coasts of France

mined by using the supernatant extracts diluted to $1 \%$ final. Microplate measurements were done on a Fluoroskan II apparatus (Grzebyk \& Galgani 1991). Illumination by excitation light, as well as reception of emission light due to resorufin fluorescence, was done vertically for each well of the plate. Each plate was read in $1 \mathrm{~min}$. Kinetics were linear for $10 \mathrm{~min}$. An external resorufin standard was used to calibrate the apparatus for conversion of fluorescence units into molar quantities (pmol). Results are classically expressed in pmol $\mathrm{min}^{-1} \mathrm{mg}^{-1}$ protein

Statistics. Means ( \pm SD) at each sampling site were calculated. The differences in EROD activity amongst stations were tested using Student's $t$-test.

\section{RESULTS}

Data collected during the surveys showed the distribution of Callionymus lyra along the western coasts of France. The main features of species density distribution were observed during the 3 cruises in autumn and spring. It was determined that dragonet are present, regardless of season, along the entire continental shelf. 


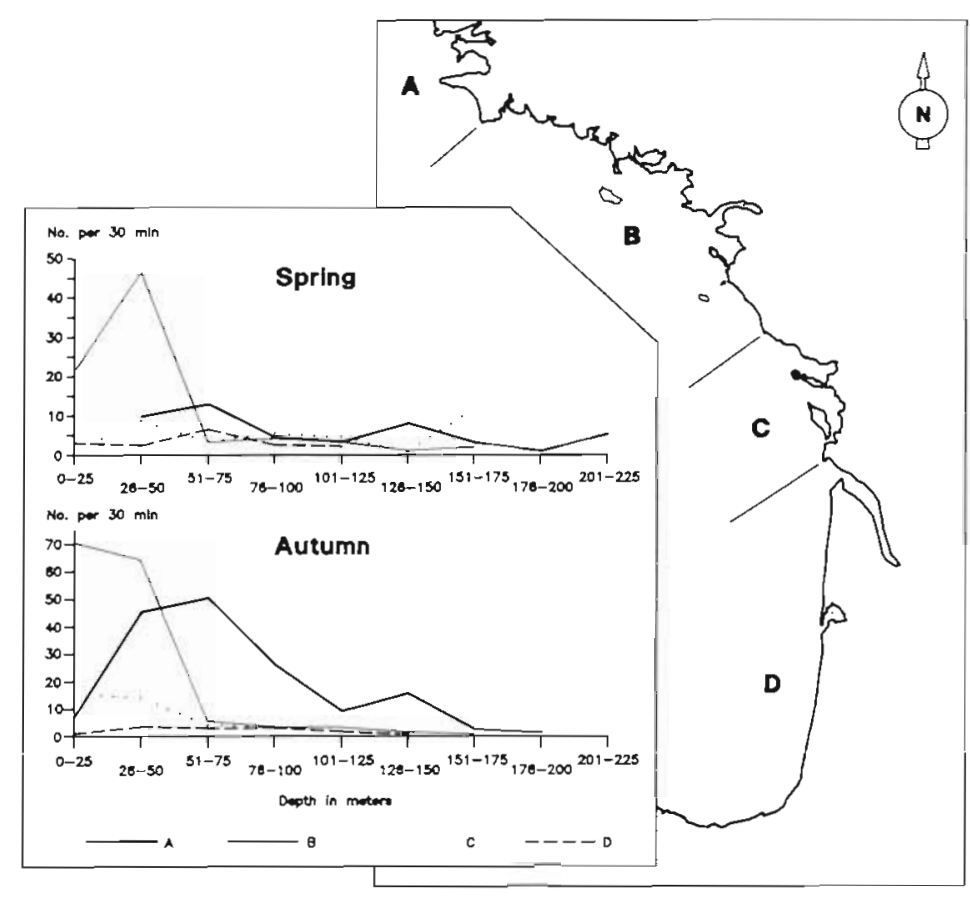

Fig. 5. Callionymus lyra. Bathymetric distribution according to geographical areas and seasons in the Bay of Biscay. Data obtained during the EVHOE cruises 1987 to 1991

In the Bay of Biscay, yields are generally lower in the spring, and the species is more dispersed then toward the open sea (Fig. 3b). Seasonal distribution varied less in the middle of the Bay of Biscay than in the northern part.

The distribution was generally more coastal in autumn, and bathymetric dispersion was greater in spring. Bathymetric distribution was less seasonal in Zone B than in Zone A (Fig. 5). The frequency distribution of dragonet length was determined by measuring the total length of all specimens fished in spring 1991. For the entire study area, sizes (Fig. 6) were between 4 and $29 \mathrm{~cm}$, males being markedly larger than females.

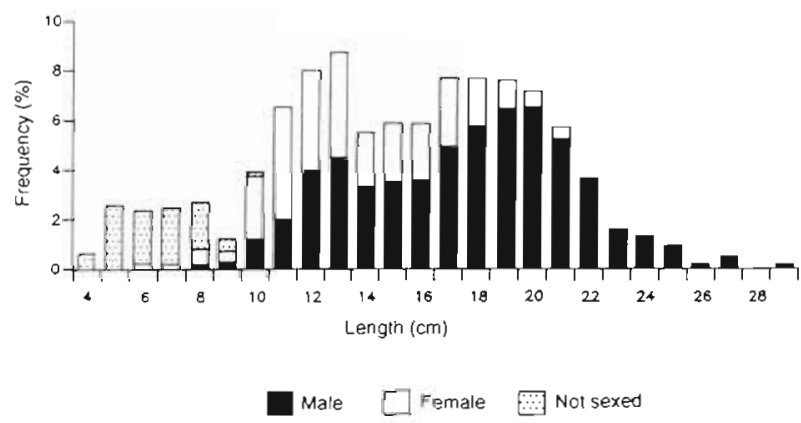

Fig. 6. Callionymus lyra. Length frequency distribution in the Bay of Biscay, spring 1991
The histogram for the entire bay shows 2 modes: $\mathrm{ca} 13 \mathrm{~cm}$ and 17 to $18 \mathrm{~cm}$. The sex ratio (no. of males to total no. of fish) was on average greater than 0.5 and slightly higher in spring. Regardless of season, the sex ratio tended to increase with depth.

Changes in the abundance of dragonet according to year and season were studied in the Bay of Biscay. Results were very comparable for the autumn EVHOE cruises from 1988 to 1990 (Fig. 7) with greater abundance in the northern part of the bay and a progressive decrease from north to south, whereas this situation was reversed in 1987. In spring 1988 and 1991, abundance was characteristically low in the northern part of the bay. Results for the last 2 cruises (1990 and 1991) showed an increase of abundances in Areas $B$ and $C$ (Fig. 5) which would seem to be independent of seasonal influence. The very wide confidence interval for the 1987 index (Fig. 5 ) is attributable to the high concentration (up to 450 ind. tow ${ }^{-1}$ ) north and south of Belle-Ile. However, in spring 1988 yields were low and uniformly distributed.

Autumn results for 1988, 1989 and 1990 were very similar, with generally stable abundances.

Biochemical characterization of EROD activity in Callionymus Iyra was performed to define the specificity of the EROD system for the species. Measurements of EROD enzymatic activity were performed in the liver since most of the activity is centered in that organ (Grzebyk \& Galgani 1991). Variations in EROD activity were influenced by the buffer and its $\mathrm{pH}$. Maximal activities were found for TRIS $(0.1 \mathrm{M}, \mathrm{pH} 8.5)$ and phosphate (0.1 M, pH 7.8) buffers. Use of these types of buffer here as recommended in the standard method (Galgani \& Payne 1991) at pH 8 provided optimal conditions for analysis.

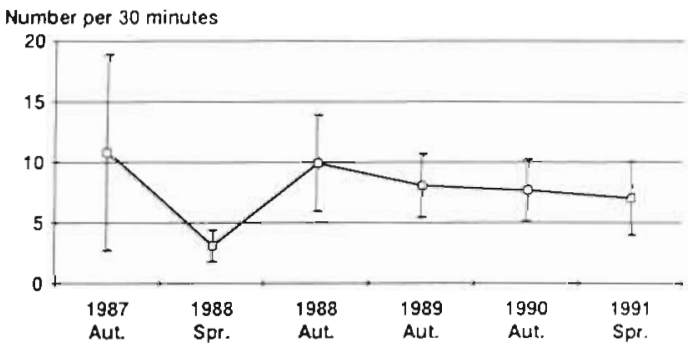

Fig. 7 Callionymus lyra. Changes in apparent abundance indices ( \pm 2 SD), spring and autumn surveys, 1987 to 1991. Abundance indices were calculated using the area swept technique, with direct application of the stratified sampling method 
Metyrapone was added to the microsomal fraction. This compound is capable of inhibiting EROD activity in the studied standard analytic conditions. EROD activity remained at $90 \%$ (of the EROD activity in standard condition) for concentrations of 0.1 to $0.5 \mathrm{mM}$ of metyrapone but decreased rapidly at concentrations above $0.5 \mathrm{mM}$.

The influence of temperature on EROD stability was studied to determine the best experimental conditions. Quantities of an enzymatic extract with known activity at $22{ }^{\circ} \mathrm{C}$ (standard conditions) were maintained at 22 , 37 and $4^{\circ} \mathrm{C}$ for $4 \mathrm{~h}$, and measurements were then performed at these temperatures. The survival curve indicating residual enzymatic activity as a function of heating time is given in Fig. 8. The stability of EROD

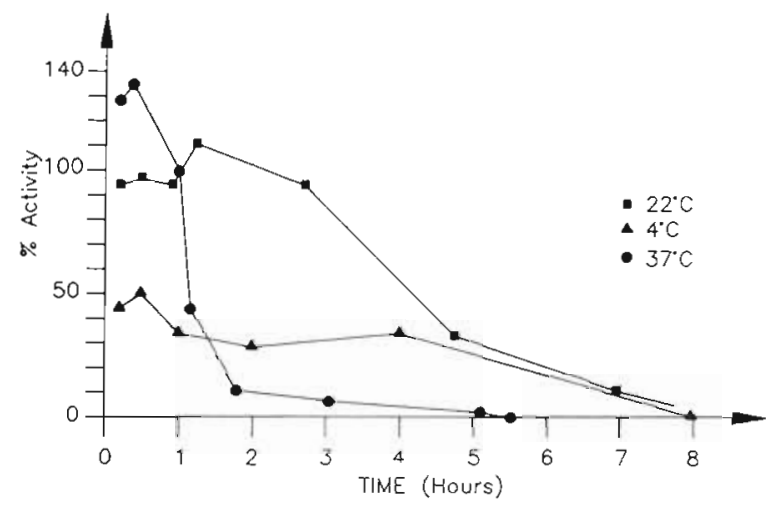

Fig. 8. Callionymus lyra. Temperature effect on the stability of EROD activity in dragonet liver

activity at $22{ }^{\circ} \mathrm{C}$ allowed $95 \%$ of activity in the standard condition to be obtained after incubation for $24 \mathrm{~h}$. The enzymatic activity of the dragonet is optimal at $37{ }^{\circ} \mathrm{C}$ after 30 min incubation of the enzymatic extract but then declines very rapidly.

The kinetic parameters (apparent $K_{\mathrm{m}}$ and $V_{\mathrm{m}}$ ) of EROD activity were determined in dragonet liver according to the method of Eadie-Hofster (Galgani et al. 1991b). The absolute value of the slope of the curve gave $K_{\mathrm{m}}=103.76 \mathrm{nM}^{-1}$, and the ordinate at its origin gave $V_{\mathrm{m}}=24.72 \mathrm{pmol} \mathrm{min}{ }^{-1} \mathrm{mg}$ of protein (Fig. 9).

The dependence of EROD activity on the NADPH cofactor was also determined. The value indicates that system saturation was reached in our NADPH solution (Fig. 10).

The first results obtained for the western coast of France are relatively homogeneous in the Bay of Biscay and the north of the channel. The absence of significant EROD induction variations observed between the different stations sampled in the open sea and near the coasts does not indicate a significant exposure to the chemical pollutants. The lack of evident

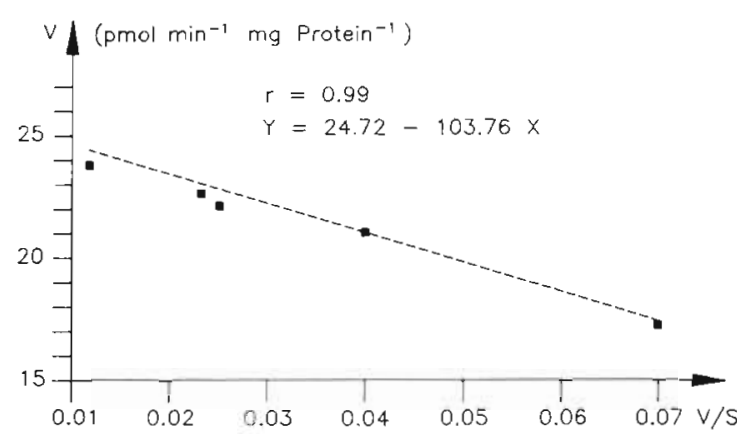

Fig. 9. Callionymus lyra. Determination of the kinetic parameters (apparent $K_{\mathrm{m}}$ and $V_{\mathrm{m}}$ ) of EROD activity in dragonet liver according to the method of Eadie-Hofster. The absolute value of the slope was $K_{m}=103.76 \mathrm{nM}^{-1}$, and the $y$-intercept was $V_{\mathrm{m}}=24.72 \mathrm{pmol} \mathrm{min}^{-1} \mathrm{mg}$ protein ${ }^{-1}$

response cannot necessarily be interpreted as meaning there has been no exposure. Interactive effects of other pollutant types (Lee et al. 1980) could severely limit the response and the interpretation. However we have identified significant induction in specific sites such as Seine Bay and Saint Brieuc Bay.

No significant difference was observed in the Seine Bay between Stns 1 and $4(\mathrm{p}=0.106)$ which seem to be less influenced by the contaminated flux of the Seine River (Salomon 1986). But a significant difference was demonstrated there between Stns 1 and $3(p=0.047)$ as well as between Stns 1 and $2(p=0.005)$, Stn 2 being located in a zone near the Seine estuary. EROD measurements in dab Limanda limanda at Stns 1 and 2 for the same period (Table 1) showed a comparable difference, indicating that the dispersion of contaminants in Seine Bay depends on the dilution flow of the Seine River.

EROD activity was of the same order of magnitude for both dab and dragonet. Induction of EROD activity in the subestuarial zone ( $\operatorname{Stn} 2$ ) showed more exposure of fish to contaminant than in the center and the western coast of Seine Bay. These findings are concordant

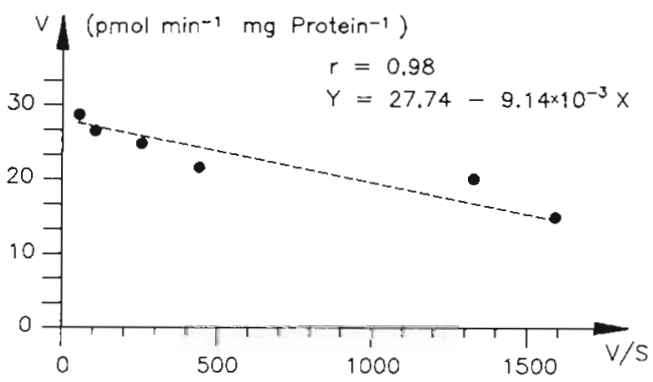

Fig. 10. Callionymus lyra. EROD activity dependence for NADPH in dragonet liver. The absolute value of the slope gave the apparent affinity of $9.14 \times 10^{-3} \mathrm{mM}^{-1}$ of the EROD system for NADPH 
Table 1. Callionymus lyra and Limanda limanda. Induction of EROD activity in Seine Bay

\begin{tabular}{|lccc|}
\hline Species & Stns & \multicolumn{2}{c|}{$\begin{array}{c}\text { EROD activity } \\
\text { (pmol min }\end{array}$} \\
& \multicolumn{4}{c|}{ Aug $^{-1}$ protein) } \\
Aug 199 & Mar 1991 \\
\hline Callionymus lyra & 1 & $6.1 \pm 1.9$ & - \\
& 2 & $18.2 \pm 6.3$ & - \\
& 3 & $14.9 \pm 6.7$ & - \\
Limanda limanda & 1 & $4.3 \pm 2.7$ & $2.38 \pm 2$ \\
& 2 & $18.3 \pm 10.16$ & $11.15 \pm 5.4$ \\
& 3 & - & $5.03 \pm 3.71$ \\
\hline
\end{tabular}

with PCB measurements in Seine Bay sediments and mollusks (Claisse 1989, Galgani et al. 1991a). Assessment of specific PCB congeners demonstrated a higher level of pollutant in the subestuariai zone 15 to $20 \mu \mathrm{g} \mathrm{l}^{-1}$ ) than in the center and the western coast ( 3 to $10 \mathrm{ng} \mathrm{l}^{-1}$ ) (Abarnou \& Simon 1986).

High induction of EROD activity $(33 \pm 10.9 \mathrm{pmol}$ $\mathrm{min}^{-1} \mathrm{mg}^{-1}$ protein) was found at Stn 13 Saint Brieuc Bay. This result, based on 5 individuals instead of 10 as at $\operatorname{Stn} 10$, indicates the sensitivity of Callionymus lyra to pollutants at a sufficient concentration for induction of EROD activity. These first series of data collected in 1991 require confirmation and comparison with chemical analysis of PCB, in the context of the monitoring network to be set up in 1992 .

\section{DISCUSSION}

The criteria for biomarker use and the choice of a target species have been defined with respect to assessment of the effect of chemical pollutants on the environment. The conditions proposed during international meetings (Giam 1978, Bayne et al. 1980, Lee et al. 1980, Uthe et al. 1980, Galgani \& Payne 1991) were respected in this study. The target species should be widely distributed, indigenous, ecologically important and capable of being maintained in laboratory conditions. Detailed information on its biology, physiology and biochemisty should be known.

The purpose of our study, with respect to these monitoring criteria, was to determine the most suitable species for EROD analysis along the French coasts. An oceanographic cruise along the English Channel and Atlantic coasts indicated the utility of EROD measurements as a biomarker of chemical contaminations (Lech et al. 1982, Lindström Seppä et al. 1985, Buhler \& Williams 1989, Burgeot et al. 1992) in Callionymus lyra. Since Linneaus first established the genus Callionymus in 1758 the classification of this family has been revised several times. The classification of the Callionymidae was examined and its genera are reviewed on the basis of specimens from almost all parts of the world (Fricke 1981, Nakado 1982). Various aspects of the biology of this species have been demonstrated but it has been little studied in France. Works on the behavior of dragonet show that they live in contact with sediment or sand and feed essentially on invertebrates, worms and crustaceans (Davis 1966, Johnson 1973). C. lyra is an epibenthic species characterized by a spawning season ranging from April to September, depending on geographical areas (Gibson \& Ezzi 1979, Yongshu et al. 1989). A study at a French site (Douarnenez Bay on the Atlantic coast) demonstrated the specific nature of its biology in that region (Hamou-Tahra 1977, Durand 1980). The mating period occurs in January and February, and males can lose up to $70 \%$ of their weight at that time. Dragonet live preferentially in waters with a temperature close to $13^{\circ} \mathrm{C}$. Males may live up to $5 \mathrm{yr}$, while the females may live 2 yr longer. An analysis of the rates of growth of the spent males showed that the rate of growth is highest in the third-year breeders, and lowest in the fifth-year breeders (Chang 1951).

The stability of dragonet abundance along the western coast in spring and autumn (the periods covered by the different cruises) is a very useful criterion for monitoring the effects of chemical contaminants on the marine environment. A detailed study of the EVHOE cruise in the Bay of Biscay showed a progressive decrease in dragonet abundance from the north toward the south (Fig. 1). The more coastal nature of its distribution in the bay in autumn and its greater bathymetric dispersion in spring (Fig. 5) are helpful criteria for determining a monitoring sampling strategy. As Callionymus lyra seemed to be a satisfactory choice in terms of the monitoring criteria defined above, we determined its biochemical characterization. With respect to inhibition of EROD activity, the MFO system appears to be less sensitive to metyrapone in the dragonet than in plaice Pleuronectes platessa and flounder Platichthys flesus (Grzebyk \& Galgani 1991). In the same analytic conditions and for the same concentration of metyrapone $(0.5 \mathrm{mM})$, residual EROD activity was $91 \%$ in the dragonet and only $10 \%$ in the plaice.

Numerous studies involving different species in various parts of the world have shown a correlation between the levels of cytochrome P-450-IA1 induction and the levels of aromatic and chlorinated hydrocarbons in the environment (Payne et al. 1987, Stegeman et al. 1987, 1988, Stegeman \& Lech 1991). A study in Seine Bay in the English Channel (Galgani et al. 1991a) demonstrated that PCBs are responsible for cytochrome P-450-IA 1 induction in plaice and dragonet. The sampling strategy for EROD activity measure- 
ment adopted during that study was then applied along the entire western coast of France.

EROD measurements in dragonet liver using the rapid microplate-reading method (Galgani \& Bocquené 1989, 1991) allowed real-time assessment of biological effects in western coastal waters. During a $3 \mathrm{wk}$ period, we integrated the natural variations in this single species relative to biotic and abiotic parameters. The background variation in the level of cytochrome P-450-IA 1 was found to be limited and identical for all stations sampled (Goksøyr et al. 1992). Except for the Seine Bay and Saint Brieuc Bay sites where significant variations in induction were observed, EROD activity in the dragonet was relatively homogeneous for the reference stations sampled at sea (around $48 \mathrm{~km}$ from the coast) and those near the shore more contaminated by pollutants of anthropogenic origin. The high induction of EROD activity measured in Saint Brieuc Bay (Fig. 4) will be studied in the future to check whether the data are valid. This first study was characterized by a wide sweep along the western coast. Subsequent studies targeted more on sensitive sites such as large estuaries, and involving more frequent sampling, should indicate whether this first assessment of biological effects was correct. A network will be set up in 1992 for biannual monitoring (spring and autumn) along the English Channel and Atlantic coasts of France. Seine Bay, which is heavily contaminated by PCB and PAH (Abarnou \& Simon 1986, Claisse 1989), will be the pilot site for monitoring start-up. The objective is to estimate the chronic effects of chemical contaminants (PCB, PAH and dioxins) on marine organisms. Measurements of EROD activity induction in dragonet liver will be performed using a sampling strategy integrating the biological characteristics of this species.

The biology of Callionymus Iyra, notably its wide distribution, make this fish a particularly useful species for evaluating the biological effect of hydrocarbon contaminants. The use of this target species will probably be extended to the monitoring of other contaminants such as radionuclides.

Acknowledgements. We thank M. J. Guesselin for secretarial assistance, $\mathrm{L}$. Giboire for providing the figures and L. Quiniou for data about the dragonet.

\section{LITERATURE CITED}

Abarnou, A., Simon, S. (1986). La baie de Seine (GrecoManche). University of Caen, April 24-26, 1985. IFREMER Actes de colloques no. 4 1986, Caen, p. 471-476

Addison, R. F., Payne, J. F. (1986). Assessment of hepatic mixed function oxidase induction in winter flounder (Pseudopleuronectes americanus) as a marine petroleum pollution technique. Can. Tech. Rep. Fish. Aquat. Sci. 1505
Bayne, B. L., Anderson, J., Engel, D., Gilfilan, E., Hoss, D., Illoyd, R., Thurberg, F. P. (1980). Physiological techniques for measuring the biological effects of pollution in the sea. Physiology panel report. Rapp. P.-v. Réun. Cons. int. Explor. Mer 1979: 88-99

Bradford, M. (1976). A rapid method for quantification of protein utilising the principle of dye binding. Analyt. Biochem. 72: 248-264

Buhler, D. R., Williams, D. E. \{1989\}. The role of biotransformation in the toxicity of chemicals. Aquat. Toxicol. 11: 19-28

Burgeot, T., Bocquene, G., Truquet, P., Le Dean, L., Galgani, F. (1992). Induction of EROD activity in red mullet (Mullus barbatus) along the French Mediterranean coasts. Sci. total Environ. (in press)

Burke, M. D., Mayer, R. T. (1974). Ethoxyresorufin: direct fluorimetric assay of microsomal O-dealkylation which is preferentially inducible by $\beta$-methylcholanthrene. Drug Metabol. Dispos. 2: $583-588$

Chang, H. (1951). On Callionymus reticulatus $\mathrm{C}$. et $\mathrm{V}$. and its distribution in European seas. J. mar. Biol. Ass. U.K. 30: 297-312

Claisse, D. (1989). Chemical contamination of French coasts: the results of ten years of mussel watch. Mar. Pollut. Bull. 20: $523-528$

Davis, W. P. (1966). A review of the dragonets (Pisces: Callionymidae) of the Western Atlantic. Bull. mar. Sci. 16(4): $834-862$

Durand, A. (1980). Quelques aspects du régime alimentaire de Callionymus lyra. Mémoire présenté à l'Université de Bretagne Occidentale pour un D.E.A., Brest

Eggens, M., Galgani, F., Klungoyr, J., Everts, J. (1992) Hepatic EROD activity in the dab Limanda limanda in the German Bight using an improved plate-reader method. Mar. Ecol. Prog. Ser. 91: 71-75

Fricke, R. (1981). Revision of the genus Synchiropus (Teleoster: Callionymidae). Theses zoologicae, 1. Verlag J. Gramer, Braunschweig

Galgani, F., Bocquene, G. (1989). Utilisation des lecteurs de microplaques pour les mesures colorimétriques et enzymatiques. Oceania 15(4): 433-441

Galgani, F, Bocquene, G. (1991). Semi-automated colorimetric and enzymatic measurements in aquatic organisms using a plate reader. Wat. Res. 25(2): $147-150$

Galgani, F., Bocquene, G., Lucon, M., Grzebyk, D., Letrouit, F., Claisse, D. (1991a). EROD measurements in fish from the northwest part of France. Mar. Pollut. Bull. 10: 494-500

Galgani, F., Bocquene, G., Truquet, P., Burgeot, T., Chiffoleau, J. F., Claisse, D. (1992). Monitoring of pollutant biochemical effects in marine organisms of the French coasts. Oceanol. Acta 15: 355-364

Galgani, F., Cadiou, Y., Bocquene, G. (1991b). Routine determination of enzyme kinetics using plate reader. Biotechnol. Bioeng. 38: 434-437

Galgani, F., Payne, J. F. (1991). Biological effects of contaminants: microplate method for measurement of ethoxyresorufin-O-deethylase (EROD) in fish. ICES Technique in Marine Environmental Sciences No. 13, Copenhagen

Giam, C. S. (1978). Pollution effects on marine organisms. Lexington Books, Lexington, MA

Gibson, R. N., Ezzi, I. A. (1979). Aspects of the biology of the spotted dragonet Callionymus maculatus RafinerqueSchmaltz from the west coast of Scotland. J. Fish Biol. 15: $555-569$

Goksøyr, A. (1987). Characterization of the cytochrome P450 Monooxygenase system in fish liver metabolism and effects of organic xenobiotics. Ph.D thesis, University of Bergen 
Goksøyr, A., Forlin, L. (1992). The cytochrome P-450 system in fish, aquatic toxicology and environmental monitoring. Aquat. Toxicol. 22: 287-312

Goksøyr, A., Solbakken, J. E., Klungsoyr, J. (1986). Regioselective metabolism of phenanthrene in Atlantic cod (Gadus morhua): studies on the effects of monooxygenase inducers and the role of cytochrome P-450. Chem. Biol. Interact. 60: 247-263

Gooch, J. W., Elskus, A. A., Klowpper-Sams, P. J., Hahn, M.E., Stegman, J. J. (1989). Effects of ortho and non-orthosubstituted polychlorinated biphenyl congeners on the hepatic monooxygenase system in scup (Stenotomus chrysops). Toxicol. appl. Pharmacol. 94: 246-253

Grzebyk, D., Galgani, F. (1991). Measurement of organic pollution in marine organisms. Rapid determination of EROD induction using plate readers. Aquat. Living Res. 4: 53-59

Hamou-Tahra, J. (1977). Croissance et fécondité de Callionymus lyra en baie de Douarnenez. Mémoire présenté à l'université de Bretagne Occidentale pour un D.E.A., Brest

Johnson, C. R. (1973). Biology of the dragonet, Callionymus kaianus moretonensis Johnsen (Pisces: Callionymidae). Zooi. J. Linn. Soc. 52: 217-230

Lech, J. J., Vodicnik, M. J., Elcombe, C. R. (1982). Induction of monooxygenase activity in fish. In: Weber, L. J. (ed.) Aquatic toxicology. Rouen Press, New York, p. 107-148

Lee, R., Davies, J. M., Freeman, H. C., Ivanovic, A. (1980) Biochemical techniques for monitoring blological effects of pollution in the sea. Rapp. P.-v. Réun. Cons, int. Explor. Mer 179: 48-55

Lindstrom Seppä, P., Koivusaari, U., Hanninen, O., Pyysalo, H. (1985). Cytochrome P-450 and monooxygenase activities in the biomonitoring of the aquatic environment. Pharmazie 40: 232-234

Monod, G., Devaux, A., Riviere, J. L. (1988). Effects of chemical pollution on the activities of hepatic xenobiotics metabolizing enzymes in fish from the river Rhône. Sci. total Environ. 73: 189-201

Nebert, D. W., Nelson, D. R., Adesnick, M. (1989). The P-450 superfamily: updated listing of all genes and recommended nomenclature for the chromosomal loci. DNA 8 : $1-13$

Olney, J. E., Sedberry, G. R. (1983). Dragonet larvae (Teleostei, Callionymidae) in continental shelf waters off the eastern United States. Biol. Oceanog. 3: 103-122

Payne, J. F., Fancey, A., Rahimtula, D., Porter, E. L. (1987). Review and perspectives on the use of mixed function oxygenase enzymes in biological monitoring. Comp. Biochem. Physiol. 86C: 233-245

Payne, J. F., Kiceniuk, J., Fancey, L., Williams, U., Fletcher, G. L., Rahimtula, A., Fowler, B. (1988). What is the safe level of polycyclic aromatic hydrocarbons in fish? Subchronic toxicity study on winter flounder (Pseudopleuronectes

This article was submitted to the editor americanus). Can. J. Fish. Aquat. Sci. 45(11): 1983-1993

Prough, R. A., Burke, M. D., Mayer, R. T. (1978). Direct fluorometric methods for measuring mixed function oxidase activity. Meth. Enzymol. 52: 372-377

Salomon, J. C. (1986). Courantologie calculée en baie de Seine. IFREMER-CNRS Actes de colloques no. 4, Caen, p. $35-42$

Spies, R. B., Rice, D. W. Jr, Felton, J. (1989). Effects of organic contaminants on reproduction of the starry flounder Platichthys stellatus in San Francisco Bay. I. Hepatic contamination and mixed function oxydase (MFO) activity during the reproductive season. Mar. Biol. 98: 181-189

Stegeman, J. J., Kloepper-Sams, P. J. (1987). Cytochrome P-450 isozymes and monooxygenase activity in aquatic animals. Environ. Hlth Perspect. 71: 87-95

Stegeman, J. J., Lech, J. J. (1991). Cytochrome P-450 monooxygenase systems in aquatic species : carcinogen metabolism and biomarkers for carcinogen and pollutant exposure. Environ. Hith Perspect. 90: 101-109

Stegeman, J. J., Teng, F. Y., Snowberger, E. A. (1987). Induced cytochrome P.450 in winter flounder (Pseudopleuronectes americanus) from coastal Massachusetts evaluated by catalytic assay and monoclonal antibody probes. Can. J. Fish. Aquat. Sci 44: 1270-1277

Stegeman, J. J., Woodin, B. R., Goksøyr, A. (1988). Apparent cytochrome P-450 induction as an indication of exposure to environmental chemicals in the flatfish Platichthys flesus. Mar. Ecol. Prog. Ser. 46: 55-60

Suteau, P. (1987). Biotransformation des xénobiotiques chez un bivalve marin: recherche intégrée pour la définition de tests de toxicité à terme. Thèse Université de Bordeaux I, Bordeaux

Tetsuji, N. (1982). Revision of genera of the dragonet (pisces: Callionymidae). Publs Plymouth mar biol Lab. (1/3): $77-131$

Uthe, J., Freeman, H., Mounir, S., Lokhart, W. (1980). Selection of biochemical techniques for detection of environmentally induced sublethal effects in organisms. Rapp. P.-v. Réun. Cons. int. Explor. Mer 179: 39-47

Van Veld, P. A., Westbrook, D. J., Woodin, B. R., Hales, R. C., Smith, C. L., Huggett, R. J., Stegeman, J. J. (1990). Induced cytochrome P-450 in intestine and liver of spot (Leiostomus xanthurus) from a polycyclic aromatic hydrocarbon contaminated environment. Aquat. Toxicol. 17: $119-132$

Vodiccnik, M. J., Elcombe, C. R., Lech, J. J. (1981). The effect of various types of inducing agents on hepatic microsomal monooxygenase activity in rainbow trout. Toxicol. appl. Pharmacol. 59: 364-374

Yongzhu, K. F., Aida, K., Hanyu, I. (1989). Annual reproductive rhythm of the Tobinumeri dragonet Repromucenns beniteguri (callionymidae) in Lake Hamana. Nippon Suisan Gakk. 55(4): 591-599

Manuscript first received: September 29, 1992

Revised version accepted: March 31, 1993 